\title{
An Analysis of Basic Interaction, Communication, Team Building, and Problem-solving Skills of Primary School Students in Marching Band Activities
}

\author{
Deden Herdiana Altaftazani ${ }^{凶}$, Galih Dani Septiyan Rahayu2, Jajang Bayu Kelana ${ }^{3}$ \\ 1,2,3, Primary Teacher Education Department, IKIP Siliwangi, Cimahi, Indonesia \\ $\triangle$ deden@ikipsiliwangi.ac.id
}

\begin{abstract}
This research is motivated by the importance of social skills for elementary school students. Social skills are abilities that must be possessed by every individual to function well in their social environment. Social skills must be instilled through the stages of learning and habituation. One of the approaches to instill social skills is through marching band activities. This research aimed at finding out how marching band activities can emerge and develop students' social skills. This research used a qualitative approach with a case study research design. Three ways of collecting data were used to obtain data, which are interviews, observation, and documentation. As a result, marching band activities can bring up various social skills of students, including basic interaction skill, basic communication skill, team or group building skill, and problem-solving skill. Meanwhile, the factors that influenced the formation of social skills in marching band activities in elementary schools are group activity factor, situation factor, regulatory factor, program or design factor, and peer relationship factor.
\end{abstract}

Keywords: Social Skills, Marching Band, Interaction, Communication, Team Building, Problem Solving

How to Cite: Altaftazani, D. H., Rahayu, G. D. S., \& Kelana, J. B. (2020). An Analysis of Basic Interaction, Communication, Team Building, Problem-solving skills of Primary School Students in Marching Band Activities. Mimbar Sekolah Dasar, 7(2), 184-197. doi: http://dx.doi.org/10.17509/mimbar-sd.v7i2.26264

INTRODUCTION Essentially, humans are born as social creatures. However, the social nature in humans is not automatically owned, it is obtained from various life processes experienced by them. Humans will learn from every experience they got in every life process that they have lived. Social skills are one of the important factors that can help students in the process of interaction with their environment. Lack of social skills in students will make them more likely to experience difficulties in interacting with their environment. This is based on the principle that humans are social beings, who will always need the help of others, and who will always interact with other living things and the surrounding environment. Therefore, humans are expected to have various abilities to support the interaction activities in their social life (Baton et al., 2019 ; OECD, 2015). Humans must be trained as early as possible to have social skills, so they can live comfortably in their social environment (Suswandari et al., 2020). Social skills are not abilities that are automatically possessed by every human being from birth, it must be trained and familiarized through the learning process, which can be of various things. Social skills in children can be learned from their parents as they are the closest persons the children 
Deden Herdiana Altaftazani et al., An Analysis of Basic Interaction...

have or through learning with friends and their surrounding community (Segrin, 2000; Begazo et al., 2019).

Social skills are closely related to social behavior. The early childhood stage in humans is the stage where they tend to apply this behavior quickly because at this time, they will learn the behavior of others and start interacting with their peers. If this process does not work well, anti-social behavior will emerge. Social behavior on children depends on three things; first, their desire to live in a social environment; second, how do they develop their behavior for the better; and third, intellectual abilities about their understanding of the relationship between social behavior and the ease of interaction in their community (Idawati et al., 2020; Ruskandi et al., 2019; Altaftazani et al., 2020). One way to instill social skills can be done through extracurricular activities in schools. One of them is the marching band extracurricular activities, which can help students practice their social skills.

In several studies, it was explained that marching band activities are closely related to character. Dagaz (2012) in her research entitled "Learning from the Band: Trust, Acceptance, and Self-Confidence", argued that marching band activities can foster mutual trust among band members, will lead to good acceptance of fellow members, thus giving rise to good interaction among all members. From this mutual trust and acceptance of each other, marching band activities can shape its members into human beings who have good selfconfidence. In another study written by Cumberledge (2017) entitled "The Benefits of College Marching Bands for Students and Universities: A Review of the Literature", it was explained that marching band activities have many benefits. Apart from being beneficial for the character development of students, marching band activities also have benefits for their schools or educational institutions. In addition, in another study written by Hermawan (2017) entitled "Marching band as character education: a comprehensive solution for non-formal education for adolescents", it was explained that marching band activities have an important role in developing character education for students.

From these three studies, it can be inferred that marching band activities have various benefits for students. That is what underlies us to conduct research on marching band activities. The research we conducted was more specific to the analysis of social skills in marching band activities. Analysis of the extent to which marching band activities can generate social skills including basic interaction skills, communication skills, team building skills and problem solving skills. 


\section{LITERATURE REVIEW}

\section{Social Skills}

Social skill is a variety of abilities that allow children to interact with friends and their environment, in ways that are socially acceptable. It can also be learned and trained as early as possible from simple things to complicated things like smiling, getting to know friends in their environment, asking for help, expressing feelings, expressing opinions, defending what is right, and carrying out discussion activities (Madrona et al., 2014).

In other words, social skills are a set of skills that must be possessed by someone, especially children. With these skills, it will be possible for children to get along and interact well with their peers and adults (Denault \& Déry, 2015). Social skills are something that must be learned. Acceptable behavior in social life is when human beings showed positive interactions with one another. Social skills are very important to achieve success in the academic world, as well as in the community. In other words, social skills are not something that occurs naturally. Social skills must be learned, trained, and accustomed (Gresham et al., 201 la).

Humans can live well if they have social skills, because humans are social beings who cannot live alone as they will always need other people. Therefore, they must be able to communicate and interact well with each other. As a social creature, humans will always live in a society or organization. This is where social skills come into play. People with good social skills will be able to interact competently in every organization that they go through (Lestari \& Ariesta, 2020). When someone has mastered social skills, they will involve various pro-social behaviors in doing things related to interaction with others such as helping each other, and sharing and caring for each other. That behavior basically lies in the context social and interpersonal (Kwon et al., 2014). In other words, social skills are a means of connecting one's interactions within the social sphere. Someone who does not have good social skills will be functionally disrupted and will have difficulty in adapting to various social situations that will result in decreased performance and social interaction (Bolsoni-Silva \& Loureiro, 2014).

It is hoped that through social skills, students will be able to become a person who are open to criticism from others, able to provide criticism, act according to the prevailing social norms and values, and able to adapt in any situation (Taborsky \& Oliveira, 2012). The main purpose of social skills is to form individuals who have the ability to communicate effectively with others both verbally and non-verbally, and be able to understand a variety of different social situations and conditions (Semrud-Clikeman, 2007).

Social skills can be interpreted as a set of skills that can help a person to be able to communicate, relate, and socialize with other people (Rashid, 2010). For elementary school students, social skills are something that must be instilled early. Fostering social skills in students 
Deden Herdiana Altaftazani et al., An Analysis of Basic Interaction...

have many benefits, including improving students' performance at school, reducing problems related to behavior and social pressure, and encouraging students to be able to understand that interaction in social life is an important goal of the educational process (Dam \& Volman, 2007). Having social skills early can foster high social sensitivity, because when someone wants to have the ability to understand various social cues and wants to be involved in various interpersonal interactions, a set of social skills is needed. Therefore, students must learn to grow a set of social skills so that their sensitivity to the environment and social situations can grow as early as possible (Locke et al., 2014). Social skills can also play as a role that can bind the relationship between each community as a harmonious and productive joint entity. In any situation of cooperating with others, social skills can act as a tool to achieve the goal of living together in society (Beauchamp \& Anderson, 2010).

In this research, the social skills indicators used were those proposed by Cadler (Maryani \& Syamsudin, 2009; Adery et al., 2018) that includes:

1. Basic interaction skill: In this skill, children will try to be competitive, maintain eye contact, and share information or material.

2. Communication skill: In this skill, children will try to hear and speak in turns, soften the sound, convince people to be able to express opinions, and listen to other person.

3. Team building skill: In this skill, children will try to accommodate people's opinions, work together, help each other, and care for each other.

4. Problem-solving skill (conflict resolution): In this skill, children will try to control themselves, develop empathy, think of others, obey the agreement, find a way out by discussion, and respecting different opinions.

\section{Marching Band Extracurricular}

Marching band is one type of extracurricular activities, which have an important role in the learning process in schools. Extracurricular activities carried out outside of school hours give a lot of influence on the child's personality. A good child's personality is very important to be developed in the learning activities in school (Garrison, 1986). Extracurricular activities aim at helping students to be able to deepen and broaden knowledge that is not taught in the classroom, recognize relationships between various subjects, channel talents and interests, and make efforts to foster complete human beings (Husodo, 2014). Extracurricular activities must be carried out outside school hours but still in the school area, so that the students can develop and broaden the knowledge and abilities that have been learned from various subjects in the curriculum (Madsen et al., 2007).

Extracurricular activities can help students to practice how they interact in an organization and to learn how to work together with their fellow colleagues in the organization (Eccles et 
al., 2003). By following extracurricular activities in the structure of general education, students are expected to be able to develop themselves. Extracurricular activities also aim at providing opportunities for students to develop and express themselves according to the needs, talents, and interests of each student in the school conditions. In general, the function of extracurricular activities is divided into four functions, namely development, social, recreational, and career preparation (Farb \& Matjasko, 2012).

One of the extracurricular activities carried out in school is marching band. Marching band is an extracurricular activity that focuses on playing music integrated with physical activities, and contains an artistic dimension., which is mostly done outdoors and have a schedule of exercises for a long time in a day. In addition, this activity requires motivation and teamwork to achieve common goals (Hermawan, 2012). It is an activity where a group of people play music while moving and walking to form various visualizations of movement. This is what distinguishes a marching band from other types of musical activities, because when playing a marching band, players are required to always move dynamically to the rhythm of the music being played, not to remain static in place. Marching band has three main elements, namely players, equipment, and coaches (Hermawan, 2017).

Players are a group of individuals who play their roles according to the instrument they play while a coach is an individual who makes the concept of appearance. Both concepts are related to music, physical activity, and artistic dimensions. The last element in marching band is equipment. This is the main tools used in marching band activity. There are three types of tools used in marching band activities, namely; 1) inflatable musical instruments (horn line) consist of various tools such as trumpet, mellophone, baritone, euphonium, and tubes; 2) percussion instruments consist of various tools such as snare drum, bass drum, tenor, cymbals, and Percussion In Tone (PIT); and 3) color guard, which is an equipment that gives color to the marching band appearance that consists of various tools such as flags, raffles, etc. (Altaftazani, 2017).

Many benefits can be examined from the marching band activities. The first benefit is cooperation. Marching bands can be a vehicle to practice collaboration. Because inside there is a process of cooperative relations within the group. The second benefit is that it can foster responsibility, because this activity will train a sense of connection in a community. connection understanding of the importance of accepting individual responsibility as a group member (Cumberledge, 2017). The third benefit is growing loyalty. Marching band activities require hard work and sweat, in addition it requires time and high dedication (Dagaz, 2012). In addition, the marching band also has three main functions, namely disciplinary function, art function and social function. 
Deden Herdiana Altaftazani et al., An Analysis of Basic Interaction...

\section{METHOD}

\section{Research Design}

The research employs case study method, which is to obtain empirical data when the research is conducted.. Case studies are one of the methods used in various social science studies. Hence, it is suitable to be employed for this research. In general, case studies are designed to answer research questions related to why or how (Gerring, 2006). This research was conducted for 6 months, starting from January to June 2019. The research stages carried out include the Pre-Field Stage, the planning stage, the Research Implementation Stage, the Data Analysis Stage and the data processing stage.

This research was conducted at one of the schools in Margahayu District, Bandung Regency. The participants of the research consisted of students, coaches/extracurricular trainers, principals, parents of students, and various other elements that supported the development of the research. The data collection was carried out using three methods namely observation, interview, and documentation. Data analysis technique used is data triangulation where the data from those three sources of data collection was combined (Creswell, 2007).

\section{Research Instrument}

This study used three instruments in collecting research data, namely the observation sheet, interview guidelines and analysis sheet for the study documentation. 1) The observation sheet is a document used to record/take notes, either in a structured or semistructured way of activities at the research location. The researcher made direct observations to see various student activities that would bring out social skills in marching band activities; 2) interview guidelines, which is a document that contains a list of questions related to social skills analysis in marching band activities. The researcher prepared three interview guidelines with a different list of questions, namely interview guidelines for students, interview guides for trainers and interview guides for teachers; 3) the documentary study analysis sheet is a document used to analyze the elements of social skills in certain documents. The documents analyzed in this study are documents of marching band activity and training programs in elementary schools.

\section{Research subject}

Research subjects are people who are chosen to provide various information about the research being carried out. They are a source of information to reveal facts in the field. The determination of research subjects in this study was carried out by means of purposive sampling. namely determining the sample in accordance with the research objectives. or determine the subject based on the objectives and problems raised in the research. Therefore, the appropriate subjects in this study are people who are directly involved in 
marching band activities in elementary schools. In this study, researchers selected 9 people to become research subjects. 6 people were students who took part in marching band activities aged 10-12 years, and 2 trainers aged 20-22 years and 1 teacher. The research subjects were selected based on specific objectives, in order to be able to provide the required information. Thus what the researcher needs can be obtained through the research subject as a data source.

\section{RESULTS}

The results of the research showed that extracurricular activities can bring up various social skills. The emerging skills are as follows:

\section{The Analysis of Marching Band Extracurricular Work Program Documents}

In the marching band extracurricular documentary program in one of the state elementary school, it is explained that the vision of the marching band activities in the school is creating a creative, disciplined, and cheerful generation towards glorious achievements. The mission is to form the creativity of the students in developing their interests and talents, create a team mentality that is disciplined and obedient to the existing rules, create an attitude of team members who are polite, cheerful, and happy in appearance, realize a solid and superior drum team, and gain a brilliant achievement. The training program focuses on training aspects of musicality. There are two types of songs being studied, the first is ceremonial special songs such as Indonesia Raya song and other national songs, and the second is entertainment songs.

In addition, in an interview with a marching band trainer, the trainer emphasized that the marching band activity aims at training children to be able to socialize with others. It is also being used as the main forum for developing talent in the field of music, specifically the field of marching band, and practicing children to appear early. Therefore, in this activity, students could get to know each other because this activity requires good cooperation and interaction, and to be well executed, the children must know each other first. Besides that, there were also various interactions carried out by students, such as chatting with each other or even correcting each other. Sometimes, they would tell each other if there were other children who did not understand the marching band material.

\section{Social Skills in the Marching Band Activity}

\section{Basic Interaction Skill}

Marching band activity can bring up various social skills. One of the emerging social skills is the basic interaction skill. This can be seen from the students' observation and interview. It showed that through the activity, students could interact more intensely and they become 
Deden Herdiana Altaftazani et al., An Analysis of Basic Interaction...

more familiar with each other. This is also reinforced by the trainer's opinion. According to the trainer, the marching band activity aims at training children to be able to socialize, but it can also be used as the main forum for developing talent in the field of music, especially in the field of marching band, and for children to practice to appear early. Therefore, in this activity, students could get to know each other because this activity requires good cooperation and interaction, and to be well executed, the children must know each other first. Besides that, there are also various interactions carried out by students, such as chatting with each other or even correcting each other. Sometimes, they would tell each other if there are other children who did not understand the marching band material.

\section{Basic Communication Skill}

Basic communication skill can also be trained in the marching band activity. In marching band activity, students were more willing to express opinions. In fact, they often reminded fellow players when things were not appropriate. This is a form of critical thinking from the students. The trainer also mentioned that in almost every exercise, there was always a debate between students when things went wrong. They would share their opinions but the trainer always had a way to discipline the students so that the activities conducted were still in an orderly fashion. When the students wanted to give an opinion, the trainer set a condition to each student that they must raise their hands first, then they could speak after being exhorted. That rule could make the practice situation become conducive. Besides that, it trained students to be disciplined, willing to express opinions, and want to listen to the opinions of others.

\section{Team Building Skill}

The marching band activity can train students to interact with the group. It is very possible because the activity is a group activity, whether it is in large groups, or small groups. From the results of the student activities, the marching band activity always requires students to be able to work together with their friends. They all realize that if one person makes a mistake, it will impact the overall group. This clearly will shape students to do the best possible cooperation.

It was also in line with what was delivered by the trainer stating that each activity in the marching band activity was an activity of working together. In this activity, there was a large group which is a full unit of marching band, and other small groups such as percussionists, melodists, and flag players. They will all play in the same rhythm and it requires good cooperation between all members. For example, the trainer had found students who had difficulty in every activity, but the response of other students was very good. According to him, there were students who helped to teach and provide motivation. It showed that each student cared for one another. Another example was seen when the players gave feedbacks to each other. The trainer also said that this activity has many good values for 
students, such as the value of cooperation, discipline, responsibility, showmanship, confidence, organization, communication, friendship, and much more.

\section{Problem-solving Skill}

The marching band activity can also bring up the problem-solving skill in students. In a group activity, there is always conflict. Students are required to be able to resolve the problem as soon as possible. There are various ways that students do to solve a problem, some are upset and some are able to discuss. Most of the time, it finishes with discussion. They expressed their respective opinions. The last way is that they will ask the trainer. This was conveyed by the trainer. The trainer stated that he often found students who looked upset, but according to him, it was a natural thing to happen in a group activity. All the trainer had to do is teach them how to fix the error. Usually, they will discuss with each other to solve the problem. If they could not find a solution to the problem, they would ask the trainer. When these occur, they would express their opinions and remind one another. This is a positive thing to help their development. In this activity, the trainer made a variety of rules so that the activity can run well. Most students could follow these rules, and if there were students who break the rules, there is a penalty for them.

During the activity, the trainer often found disputes among the students. When that happened, students would fight their respective arguments first with each other and if they could not find the solution, their last resort was asking the trainer. Therefore, it fosters the negotiation skill of the students. So far, the impression of students in participating in the marching band activity was quite good. Students liked to do this activity, but sometimes they would complain because of fatigue and dizziness since this activity is a tiring physical activity. The trainer expected that after the students join the marching band activity, they could learn to work together, be disciplined, interact and socialize with each other, be confident, learn to express opinions, and appreciate differences.

\section{Factors Affecting}

The factors that influence the emergence of various social skills are as follows:

1. The factor influencing the emergence of basic interaction skill in the marching band extracurricular activity is because this activity is carried out in a group, it automatically requires students to be able to carry out various interactions with fellow peers.

2. The factor influencing the emergence of basic communication skill in the marching band extracurricular activity is the situation factor. From the explanation above, it can be seen that the extracurricular activity can create natural situations that lead students to carry out various communication activities such as expressing opinions, listening to each other, and caring for each other. In addition, another factor that influences the 
Deden Herdiana Altaftazani et al., An Analysis of Basic Interaction...

emergence of the communication skill is the rules set by the trainer. These rules help students to be orderly when carrying out various communication activities.

3. The factor influencing the emergence of team or group building skill is the program factor and the design of the extracurricular activity. This activity is always carried out in a group, so that students will automatically carry out the process of interaction and communication in each group. In addition, this is also influenced by the student factors as well. Students who are familiar with group activities will easily blend in each group, but for students who are not used to it, it will take a little time for them to get used to the activity.

4. The factor influencing the emergence of the problem-solving skill is the factor of peer relationships, because each student has known each other and understood each other, there will be a feeling of companionship between them. So, when a conflict occurs, they can control themselves.

\section{DISCUSSION}

Based on the results the research, the marching band extracurricular activity can train students to always interact and communicate with each other. The communication and interaction between students always occur from the beginning of the activity to the end of the activity. This is because the marching band activity involves many people. Therefore, conversations between students are often seen, both related to the activities carried out and other things outside the activities. The unique thing is that students will try to listen to each other and talk in turns. When they express their opinions, they will learn to take turn, and when there is someone who is expressing their opinions, other students will seriously listen and then will give responses after. This arises because in the extracurricular activities, students always carry out the activities together. That is why they will easily communicate and learn to understand each other. Students will always meet with each other, have conversations, have warm chats and jokes, and tell each other various information. The more this happens, the more students will become more familiar with other students. This is consistent with what was said by spence (2003) that social skills include the ability to communicate, establish relationships with others, respect oneself and others, listen to opinions or complaints from others, give or receive feedback, give or receive criticism, and act according to norms and regulations.

In addition, the social skill emerged in the marching band activity because this activity is an activity that involves many people. This will make students to learn to work together in a group and to solve problems that arise in the middle of the group. Marching band activities are carried out over a long period of time and are a repetitive training process. Therefore, the process of developing the social skill will be more effective. The inculcation of social skill must 
also be carried out continuously and consistently. This is in accordance with the statement by (Gresham et al., 2011b) which stated that the strength of social skills can be seen when an individual knows how to do certain social skills consistently and correctly. By being trained, learned, and familiarized, an individual will be able to perform the social skills consistently, as if it has become a part of their life.

Based on the results of this research, it can be seen that the basic interaction skill is the main skills that emerge because in every extracurricular activity, students will always meet, have conversations, have warm chats and jokes, and tell each other various information. The more often this happens, the more the students are familiar with each other. When student interaction increases, communication skills between students develop. This was influenced by the marching band extracurricular activity that involved many people. There will often be conversations between students, both related to the activities carried out and other things outside the activities carried out. Good communication will ultimately result in closeness between students. From this closeness, the process of working together in the group can run well. Students will get used to working with their friends, and they will learn to care for one another and will respect each other. However, in a group situation, the potential for problems will easily arise. Since it has more people, more differences of opinion will emerge and it will lead to a lot of debate. This also happens in extracurricular activities. Problems will always arise every time an activity takes place. From this phenomenon, the students' response to these problems can be observed. There are those who look upset and angry, and there are also those who are able to discuss with other students to solve these problems. This is in accordance with what was conveyed by Matson (2009) that social skills are skills to interact, communicate, and participate in groups. Social skills need to be based on personal intelligence in the form of self-control, self-confidence, discipline, and responsibility.

\section{CONCLUSION}

In the marching band extracurricular activity, students perform various positive activities. In each activity, students always learn to understand basic interaction skill, communication skill, team building skill, and problem-solving skill. The marching band activities are carried out over a long period of time and are a repetitive training process, which can lead to a variety of positive activities. Therefore, the process of developing the social skills will be more effective and the inculcation of social skills must be carried out continuously and consistently. From the results of this research, there are factors that influence social skills including the factor of activities carried out in a group, the situation factor, the rule factor set by the trainer, the program and the design factor, the students factor, and the peer relations factor. 
Deden Herdiana Altaftazani et al., An Analysis of Basic Interaction...

\section{ACKNOWLEDGMENT}

The authors would like to thank the Rector of IKIP Siliwangi, the Head of the LPPM of IKIP Siliwangi, and the Head of the Elementary School Teacher Education Study Program who always provides motivation and encouragement to develop research and publication skills.

\section{REFERENCES}

Adery, L. H., Ichinose, M., Torregrossa, L. J., Wade, J., Nichols, H., Bekele, E., Bian, D., Gizdic, A., Granholm, E., Sarkar, N., \& Park, S. (2018). The acceptability and feasibility of a novel virtual reality based social skills training game for schizophrenia: Preliminary findings. Psychiatry Research, 270(1), 496-502. https://doi.org/10.1016/j.psychres.2018.10.014

Altaftazani, D. H. (2017). Analysis of the social skills of elementary school students in extracurricular activities: Case Study at SD Negeri Taman Kopo Indah, Margahayu District, Bandung Regency (Doctoral dissertation, Indonesian Education University). Bandung: Universitas Pendidikan Indonesia.

Altaftazani, D. H., Rahayu, G. D. S., Kelana, J. B., Firdaus, A. R., \& Wardani, D. S. (2020). Application of the constructivism approach to improve students' understanding of multiplication material. Journal of Physics: Conference Series, 1657(1), 012007. https://doi.org/10.1088/1742-6596/1657/1/012007

Baton, E., Crosland, K., \& Haynes, R. (2019). An Evaluation of a Social Skills Application for Children Who Are Homeless. Research on Social Work Practice, 29(3), 323-332. https://doi.org/10.1177/1049731517729038

Beauchamp, M. H., \& Anderson, V. (2010). SOCIAL: An Integrative Framework for the Development of Social Skills. Psychological Bulletin, 136(1), 39. https://doi.org/10.1037/a0017768

Bolsoni-Silva, A. T., \& Loureiro, S. R. (2014). The role of social skills in social anxiety of university students. Paideia, 24 (58), 223-232. https://doi.org/10.1590/1982-43272458201410

Creswell, J. W. (2007). Qualitative enquiry \& research design, choosing among five approaches. In Book.

Cumberledge, J. P. (2017a). The benefits of college marching bands for students and universities: a review of the literature. Update: Applications of Research in Music Education, 36(1), 44-50. https://doi.org/10.1177/8755123316682819

Cumberledge, J. P. (2017b). The Benefits of College Marching Bands for Students and Universities: A Review of the Literature. Update: Applications of Research in Music Education, 36(1), 44-50. https://doi.org/10.1177/8755123316682819

Dagaz, M. C. (2012a). Learning from the Band: Trust, Acceptance, and Self-Confidence. Journal of Contemporary Ethnography, 41(4), 432-461. https://doi.org/10.1177/0891241612447813

Dagaz, M. C. (2012b). Participation in organized activities and conduct problems in 
elementary school: the mediating effect of social skills. Journal of Contemporary Ethnography, 23(3), 167-179. https://doi.org/10.1177/0891241612447813

Denault, A. S., \& Déry, M. (2015). Participation in Organized Activities and Conduct Problems in Elementary School: The Mediating Effect of Social Skills. Journal of Emotional and Behavioral Disorders, 23(3), 167-179. https://doi.org/10.1177/1063426614543950

Eccles, J. S., Barber, B. L., Stone, M. R., \& Hunt, J. E. (2003). Extracurricular activities and adolescent development. Journal of Social Issues, 59(4), 865-889. https://doi.org/10.1046/j.0022-4537.2003.00095.x

Farb, A. F., \& Matjasko, J. L. (2012). Recent advances in research on school-based extracurricular activities and adolescent development. Developmental Review, 32(1), 148. https://doi.org/10.1016/j.dr.2011.10.001

Garrison, P. K. (1986). The Value of Marching Band. Music Educators Journal, 72(5), 48-52. https://doi.org/10.2307/3396614

Gerring, J. (2006). Case study research: Principles and practices. In Case Study Research: Principles and Practices. https://doi.org/10.1017/CBO9780511803123

Madrona, P., Samalot-Rivera, A., Cristina Gutiérrez Marín, E., Rodenas-Jiménez, J., \& RodenasJiménez, M. L. (2014). Improving Social Skills through Physical Education in Elementary 4th Year. American Journal of Sports Science and Medicine, 2(6-A), 5-8. https://doi.org/10.12691/ajssm-2-6a-2

Gresham, F. M., Elliott, S. N., Vance, M. J., \& Cook, C. R. (2011a). Comparability of the Social Skills Rating System to the Social Skills Improvement System: Content and Psychometric Comparisons Across Elementary and Secondary Age Levels. School Psychology Quarterly, 26(1), 27. https://doi.org/10.1037/a0022662

Gresham, F. M., Elliott, S. N., Vance, M. J., \& Cook, C. R. (201 1b). Factors affecting marching band competition result: an empirical study of indonesian marching band activity. School Psychology Quarterly, 26(1), 27. https://doi.org/10.1037/a0022662

Hermawan, M. S. (2012). Factors Affecting Marching Band Competition Result: An Empirical Study of Indonesian Marching Band Activity. SSRN Electronic Journal, 4(2), 20-26. https://doi.org/10.2139/ssrn.2066720

Hermawan, M. S. (2017a). Marching Band as Character Education: A Comprehensive Solution for Non-Formal Education for Youth. New Zealand.: Victoria University of Wellington.

Husodo, S. (2014). Improving school achievement using technical guidance in managing extracurricular activities. Jurnal Pendidikan Usia Dini.

Idawati, D., Masitoh, S., \& Bachri, B. S. (2020). Application of Learning Mobility Orientation on Social Skill of Blind Children. Journal of Education and Learning, 8(1), 196-204. https://doi.org/10.5539/jel.v9n1p196

Kwon, K., Kim, E. M., \& Sheridan, S. M. (2014). The Role of Beliefs About the Importance of Social Skills in Elementary Children's Social Behaviors and School Attitudes. Child and 
Deden Herdiana Altaftazani et al., An Analysis of Basic Interaction...

Youth Care Forum, 43(4), 455-467. https://doi.org/10.1007/s 10566-014-9247-0

Lestari, C. I. A., \& Ariesta, and F. W. (2020). The Effectiveness of the NHT Model in Improving Social Skills and Social Studies Learning Outcomes in Primary Schools. Journal of Physics: Conference Series, 1477(1), 042024. https://doi.org/10.1088/1742-6596/1477/4/042024

Locke, J., Kasari, C., \& Wood, J. J. (2014). Assessing Social Skills in Early Elementary-Aged Children With Autism Spectrum Disorders: The Social Skills Q-Sort. Journal of Psychoeducational Assessment, 32(1), 62-76. https://doi.org/10.1177/0734282913485543

Madsen, C. K., Plack, D. S., \& Dunnigan, D. P. (2007). Marching band as a recruiting organization for the university: A case study. Journal of Band Research, 43(1), 54-62.

Maryani, E., \& Syamsudin, H. (2009). Development of Social Studies Learning Programs to improve social skills competencies. Research Journal, 9(1), 10-17.

Matson, J. L. (2017). Social behavior and skills in children. In Social Behavior and Skills in Children. New York: Springer. https://doi.org/10.1007/978-1-4419-0234-4

Melgar Begazo, A. E., Flores Sotelo, W. S., Arévalo Tuesta, J. A., \& Antón de los Santos, P. J. (2019). Educational Technologies, Social Skills and Decision Making in University Students. Propósitos y Representaciones, 7(2), 448-456. https://doi.org/10.2051 1/pyr2019.v7n2.305

OECD. (2015). Skills for Social Progress: the power of Social and Emotional Skills. In OECD Skills Studies. OECD Publishing.

Rashid, T. (2010). Development of Social Skills among Children at Elementary Level. Bulletin of Education and Research, 32(1), 20.

Ruskandi, K., Hikmawan, R., \& Suwangsih, E. (2019). Project-based learning: Does it really effective to improve social's skills of elementary school students? Journal of Physics: Conference Series, 1318, No. 1, 012119. https://doi.org/10.1088/1742-6596/1318/1/012119

Segrin, C. (2000). Social skills deficits associated with depression. Clinical Psychology Review, 20(3), 379-403. https://doi.org/10.1016/S0272-7358(98)00104-4

Semrud-Clikeman, M. (2007). Social competence in children. In Social Competence in Children. New York: Springer. https://doi.org/10.1007/978-0-387-71366-3

Spence, S. H. (2003). Social Skills Training with Children and Young People: Theory, Evidence and Practice. Child and Adolescent Mental Health, 8(2), 84-96. https://doi.org/10.1111/1475-3588.00051

Suswandari, M., Siswandari, Sunardi, \& Gunarhadi. (2020). Social skills for primary school students: Needs analysis to implement the scientific approach based curriculum. Journal of Social Studies Education Research, 11 (1), 153-162.

Taborsky, B., \& Oliveira, R. F. (2012). Social competence: An evolutionary approach. Trends in Ecology and Evolution, 27(12), 679-688. https://doi.org/10.1016/j.tree.2012.09.003

Ten Dam, G., \& Volman, M. (2007). Educating for Adulthood or for Citizenship: Social competence as an educational goal. European Journal of Education, 42(2), 281-298. https://doi.org/10.1111/j.1465-3435.2007.00295.x 